\title{
In-/off-label use of biologic therapy in systemic lupus erythematosus
}

Mariele Gatto ${ }^{1 \dagger}$, Emese Kiss ${ }^{2,3+}$, Yaakov Naparstek ${ }^{4+}$ and Andrea Doria ${ }^{1 * \dagger}$

\begin{abstract}
Current therapies for systemic lupus erythematosus (SLE) include corticosteroids as a persistent mainstay and traditional immunosuppressants which are given according to disease severity, organ involvement and patient status. No treatment entails certain efficacy devoid of mild-to-moderate adverse effects. Nowadays, novel therapies are being developed aiming to target specific molecules involved in SLE development and progression which show variable effectiveness and safety. Biologic agents considered for SLE comprise monoclonal antibodies (chimeric, humanized or fully human) as well as fusion molecules or antibody fragments mostly consisting of B cell-targeted therapies beside anti-cytokines as well as T cell-targeted therapies. Encouraging evidence on biologics is mostly provided by case series or uncontrolled studies; conversely, larger randomized controlled clinical trials have frequently missed their primary endpoints with the exception of BLISS-52 and BLISS-76 trials. Actually, apart from belimumab, biologics are employed in clinical practice as off-label treatments for lupus and results are often promising, depending on specific SLE features, dose regimens and individual responsiveness.
\end{abstract}

Keywords: Systemic lupus erythematosus, Biologic therapy, Randomized controlled trials, Belimumab, Anti-B cell therapies

\section{Background}

In recent times, hope was raised in systemic lupus erythematosus (SLE) for biologic therapies that are capable of specific molecular targeting at distinct key points. Novel therapies tested in SLE comprise anti-cytokines antibodies (for example, anti-interleukin(IL)-6), anti-B cell therapies targeting either B cell surface antigens (anti-CD20, anti-CD22) or B cell survival factors (for example, anti-BLyS/APRIL monoclonal antibodies), as well as drugs intervening in B-T cell co-stimulation (CTLA4-Ig) [1-12]. It has to be noted that with the exception of belimumab most of these drugs are far from being dispensed in clinical practice $[1,13]$, and some will never become available since randomized controlled trials (RCTs) have missed their primary endpoints despite promising preliminary results. Hence, apart from belimumab, biological treatment of SLE still remains an "off-label matter", raising conflicting opinions on reasons for RCTs' failure and biologics' suitability in lupus

\footnotetext{
* Correspondence: adoria@unipd.it

${ }^{\dagger}$ Equal contributors

'Division of Rheumatology, University of Padova, Via Giustiniani, 2, 35128

Padova, Italy

Full list of author information is available at the end of the article
}

management. The aim of our commentary is to provide an overview of candidate biological therapies for SLE, in light of studies which challenge or support their applicability in clinical practice.

\section{B-cell targeted therapies}

B-cell targeted therapies represent the bulk of candidate biologic medications in SLE, with the key role consistently played by $\mathrm{B}$ cells in disease pathogenesis and progression [14] (Table 1).

\section{Rituximab and anti-CD20}

CD20 is a B lymphocyte restricted cell surface molecule that is expressed from pre-B to memory B cells, but is not found in stem cells and plasma cells. Rituximab (RTX) is a chimeric antibody against the CD20 molecule which was tested in two RCTs [2,3]. The EXPLORER (Exploratory Phase II/III SLE Evaluation of Rituximab) trial was aimed to assess RTX efficacy and safety in moderate-to-severe active non-renal SLE. RTX depleted B cells but did not significantly reduce anti-DNA levels. Unfortunately, no differences in the British Isles Lupus Assessment Group (BILAG) score and flare-free ratio 
Table 1 Biologic therapies proposed for SLE

\begin{tabular}{|c|c|c|c|c|c|c|}
\hline & Drug & Type of molecule & RCT phase & Pros for use in SLE & Cons for use in SLE & References \\
\hline \multirow[t]{10}{*}{$\begin{array}{l}\text { Anti-B cell } \\
\text { therapies }\end{array}$} & Rituximab & $\begin{array}{l}\text { Chimeric } \\
\text { anti-CD20 mAb }\end{array}$ & Phase III & $\begin{array}{l}\text { - Significantly decreased anti-dsDNA } \\
\text { antibody titers and increased complement } \\
\text { levels vs. placebo. Significantly decreased } \\
\text { lupus non-renal flares in Hispanic and } \\
\text { African American patients }\end{array}$ & $\begin{array}{l}\text { - Did not significantly improve } \\
\text { lupus outcome in either renal } \\
\text { or non-renal SLE in large } \\
\text { cohorts of SLE patients }\end{array}$ & {$[2,3]$} \\
\hline & \multirow[t]{2}{*}{ Ocrelizumab } & \multirow[t]{2}{*}{$\begin{array}{l}\text { Humanized } \\
\text { anti-CD20 mAb }\end{array}$} & \multirow[t]{2}{*}{ Phase III } & $\begin{array}{l}\text { - Significantly increased complement } \\
\text { levels and decreased anti-dsDNA titers } \\
\text { through week } 48 \text { vs. placebo }\end{array}$ & $\begin{array}{l}\text { - No significant improvement } \\
\text { in renal outcome }\end{array}$ & \multirow[t]{2}{*}[15]{} \\
\hline & & & & $\begin{array}{l}\text { - Induced numerically (non-statistically) } \\
\text { significant greater renal response } \\
\text { vs. placebo }\end{array}$ & $\begin{array}{l}\text { - Serious infections in treated } \\
\text { patients vs. placebo when } \\
\text { added to MMF }\end{array}$ & \\
\hline & \multirow[t]{2}{*}{ Epratuzumab } & \multirow[t]{2}{*}{$\begin{array}{l}\text { Humanized } \\
\text { anti-CD22 mAb }\end{array}$} & \multirow[t]{2}{*}{ Phase llb } & $\begin{array}{l}\text { - Provided clinical improvement in patients } \\
\text { receiving } \geq 2,400 \mathrm{mg} \text { cumulative dose }\end{array}$ & \multirow{2}{*}{$\begin{array}{l}\text { - No significant BILAG } \\
\text { improvement after } 12 \text { weeks } \\
\text { treatment vs. placebo }\end{array}$} & \multirow[t]{2}{*}[5]{} \\
\hline & & & & - Steroid-sparing effect & & \\
\hline & \multirow[t]{4}{*}{ Belimumab } & \multirow{4}{*}{$\begin{array}{l}\text { Fully human } \\
\text { anti-BlyS mAb }\end{array}$} & \multirow[t]{4}{*}{ Phase III } & \multirow{2}{*}{$\begin{array}{l}\text { - Significant improvement in moderate- } \\
\text { persistent active SLE outcome and } \\
\text { decreased flare rates in phase III RCTs } \\
\text { (met primary endpoints) }\end{array}$} & - No BILAG assessment & \multirow[t]{4}{*}[8,9]{} \\
\hline & & & & & $\begin{array}{l}\text { No data on CNS or severe } \\
\text { renal involvement }\end{array}$ & \\
\hline & & & & $\begin{array}{l}\text { - Significant decrease in anti-dsDNA } \\
\text { antibody titers }\end{array}$ & \multirow{2}{*}{$\begin{array}{l}\text { - No advantages by treatment } \\
\text { continuation through week } \\
76 \text { (but in post-hoc analysis) }\end{array}$} & \\
\hline & & & & - Steroid-sparing effect & & \\
\hline & Atacicept & $\begin{array}{l}\text { Soluble fully human } \\
\text { recombinant } \\
\text { anti-APRIL } \\
\text { fusion protein }\end{array}$ & Phase II & - Not available ${ }^{b}$ & $\begin{array}{l}\text { - Serious infections and } \\
\text { decreased immunoglobulin levels } \\
\text { in patients receiving MMF or } \\
\text { corticosteroids prior to atacicept }\end{array}$ & {$[6]$} \\
\hline \multirow[t]{3}{*}{$\begin{array}{l}\text { Anti-co- } \\
\text { stimulatory } \\
\text { molecules }\end{array}$} & Abatacept & $\begin{array}{l}\text { CTLA4-Ig fusion } \\
\text { protein }\end{array}$ & Phase llb & $\begin{array}{l}\text { - Reduced BILAG A polyarthritis flares } \\
\text { in a phase IIb RCT }\end{array}$ & $\begin{array}{l}\text { - Did not reduce overall } \\
\text { disease flares vs. placebo in } \\
\text { either renal or non-renal SLE }\end{array}$ & {$[10]$} \\
\hline & \multirow[t]{2}{*}{ IDEC-131 } & \multirow{2}{*}{$\begin{array}{l}\text { Humanized } \\
\text { anti-CD40 } \\
\text { ligand } \mathrm{mAb}\end{array}$} & \multirow[t]{2}{*}{ Phase II } & \multirow[t]{2}{*}{ - Ameliorated SLEDAI in a phase II RCT } & $\begin{array}{l}\text { - No significant superiority } \\
\text { to placebo }\end{array}$ & \multirow[t]{2}{*}[11,12]{} \\
\hline & & & & & $\begin{array}{l}\text { - Increased risk of } \\
\text { thromboembolic events }\end{array}$ & \\
\hline \multirow[t]{9}{*}{$\begin{array}{l}\text { Anti-cytokines } \\
\text { therapies }\end{array}$} & \multirow[t]{3}{*}{ Infliximab } & \multirow[t]{3}{*}{$\begin{array}{l}\text { Chimeric anti-TNF } \\
\text { soluble } \mathrm{mAb}\end{array}$} & \multirow[t]{3}{*}{$\begin{array}{l}\text { No RCT } \\
\text { performed }\end{array}$} & $\begin{array}{l}\text { - Effective on refractory arthritis, } \\
\text { nephritis and skin lesions in } \\
\text { open-label studies }\end{array}$ & $\begin{array}{l}\text { - Severe adverse events } \\
\text { following treatment, for } \\
\text { example, thrombosis, infections }\end{array}$ & \multirow[t]{3}{*}[16,17]{} \\
\hline & & & & $\begin{array}{l}\text { - Reduction in SLEDAI and SLICC-DI } \\
\text { in pilot studies after short-term } \\
\text { induction treatment }\end{array}$ & $\begin{array}{l}\text { - Induction of pathological/ } \\
\text { pathogenetic autoantibodies } \\
\text { (anti-dsDNA, anti-phospholipid } \\
\text { antibodies) }\end{array}$ & \\
\hline & & & & & $\begin{array}{l}\text { - Increase in IFNa levels } \\
\text { following protracted } \\
\text { administration }\end{array}$ & \\
\hline & \multirow[t]{2}{*}{ Tocilizumab } & \multirow[t]{2}{*}{$\begin{array}{l}\text { Humanized IgG1 } \\
\text { anti-IL6R mAb }\end{array}$} & \multirow[t]{2}{*}{ Phase I } & $\begin{array}{l}\text { - Significantly reduced SELENA-SLEDAI } \\
\text { score (main improvement on arthritis) }\end{array}$ & $\begin{array}{l}\text { - Neutropenia and serious } \\
\text { infections }\end{array}$ & \multirow[t]{2}{*}{ [18] } \\
\hline & & & & $\begin{array}{l}\text { - Significantly reduced lgG } \\
\text { anti-dsDNA antibody levels }\end{array}$ & - No data on severe SLE & \\
\hline & \multirow[t]{2}{*}{ Anakinra } & \multirow{2}{*}{$\begin{array}{l}\text { Non glycosylated } \\
\text { IL1Ra }\end{array}$} & \multirow{2}{*}{$\begin{array}{l}\text { No RCT } \\
\text { performed }\end{array}$} & - Improved arthritis in an open-label trial & - No long-lasting effect & [4] \\
\hline & & & & & $\begin{array}{l}\text { - No extensive data are } \\
\text { available due to very } \\
\text { low patients number }\end{array}$ & \\
\hline & Sifalimumab & $\begin{array}{l}\text { Human mAb } \\
\text { blocking }\end{array}$ & Phase I & $\begin{array}{l}\text { - Significantly reduced the rate of } \\
\text { disease flares vs. placebo }\end{array}$ & - No data on severe SLE & [19] \\
\hline & & $\begin{array}{l}\text { multiple IFNa } \\
\text { subtypes }\end{array}$ & & $\begin{array}{l}\text { - Lower request of immunosupressor } \\
\text { vs. placebo }\end{array}$ & & \\
\hline
\end{tabular}

${ }^{\mathrm{a}}$ Only biologic therapies for which published clinical studies are currently available are listed.

${ }^{b}$ the study was prematurely terminated and no efficacy measures were undertaken.

anti-dsDNA, anti-double stranded DNA; APRIL, A PRoliferation Inducing Ligand; BILAG, British Isles Lupus Assessment Group; BLyS, B Lymphocyte Stimulator; CNS, central nervous system; IFNa, interferon alpha; IgG, class G immunoglobulin; IL1Ra, interleukin 1 receptor antagonist; IL6R, interleukin-6 receptor; mAb, monoclonal antibody; MMF, mycophenolate mofetil; RCT, randomized controlled trial; SLE, systemic lupus erythematosus; SLEDAl, Systemic Lupus Erythematosus Disease Activity Index; SLICC-DI, Systemic Lupus International Collaborating Clinics group Damage Index; TNFa, tumor necrosis factor alpha. 
were observed. The Lupus Nephritis Assessment with Rituximab (LUNAR) study involved patients with proliferative lupus nephritis (LN) [5]. The primary outcome was the proportion of patients with complete or partial remission of LN at 12 months, which was not attained; two deaths (sepsis and pneumonitis) occurred in the RTX group. Evaluation of Ocrelizumab (humanized anti-CD20 monoclonal antibody, $\mathrm{mAb}$ ) in two phase III RCTs - the BEGIN (A Study to Evaluate Two Doses of Ocrelizumab in Patients With Active Systemic Lupus Erythematosus) and the BELONG (A Study to Evaluate Ocrelizumab in Patients With Nephritis Due to Systemic Lupus Erythematosus) very similar to the EXPLORER and LUNAR - was stopped prematurely due to an increase in infections in the active arm of the studies [15].

Different facts can explain the failure of these phase III RCTs testing CD-20 depleting agents in SLE, for example, the low number of patients, highly variable background of immunosuppressive therapy and high dose steroids, relatively short follow-up period, non-adequate outcome measures and, importantly, extreme endpoint stringency (no BILAG A or B, and complete renal response). However, partial favorable reports for RTX were documented in that the EXPLORER trial showed a higher percentage of complete or partial response at week 52 in African American and Hispanic patients. Statistically significant improvements in serum complement (C3 and C4) levels and decreases in anti-dsDNA antibody levels were observed among RTX-treated patients both in the EXPLORER and in the LUNAR trials $[2,3]$.

Moreover, open and uncontrolled clinical studies with RTX as well as results of French, UK and other European registries indicate promising outcomes [20-22]. Prospective and retrospective studies, as well as case series and single case reports, showed 300 patients with refractory LN being treated with RTX at different dosing regimens and analysis revealed complete or partial response to RTX in approximately two thirds of patients [23]. Notably, longitudinal observations on 50 patients with proliferative LN showed promising results following treatment with RTX $1 \mathrm{~g}$ fortnight and pulse methylprednisolone but no oral steroids in the follow-up [24]. In this study, the majority of patients were kept on partial or complete renal remission with only mycophenolate mofetil after RTX induction. However, the definition of renal remission given in this study may be objectionable and systemic as well as renal flares occurred in a relevant percentage of patients within one year.

Nevertheless, in light of "experience-based" medicine, RTX use is included in the European League Against Rheumatism (EULAR) recommendations for refractory LN [25].

\section{Anti-CD22 and Epratuzumab}

Epratuzumab is a humanized monoclonal antibody which activates the CD22 regulatory pathway on B cells [26]. It was tested in a phase IIb trial [5], where it caused a modest decrease of about $30 \%$ in B cells, without a change in immunoglobulin levels. The proportion of responders was higher in all epratuzumab groups than in placebo, but overall treatment effect was not statistically significant [5]. Two international RCTs (Alleviate Lupus Affliction with Epratuzumab and Validate its Autoimmune Safety and Efficacy (ALLEVIATE) 1 and 2) evaluating epratuzumab in patients with moderately to severe active SLE were discontinued prematurely because of interruption in the drug supply [27]. Despite that, 90 patients with moderateto-severe SLE flares responded well to epratuzumab, as it was indicated by improvements in BILAG scores and steroid sparing effects. Epratuzumab was well tolerated and significantly improved health-related quality of life. Two phase III RCTs are currently ongoing (NCT01261793; NCT01262365) [5].

\section{BAFF/BLyS and APRIL system and belimumab}

Targeting B-cell activating factor (BAFF)/B lymphocyte stimulator (BLyS) and a proliferation inducing ligand (APRIL) seems to be a suitable option in lupus. Preclinical data from experimental models and human observations confirmed high BLyS concentrations in lupus prone mice and approximately half of human lupus patients; BLyS antagonism ameliorated disease symptoms and survival in animal models [28]. When comparing RTX and belimumab, one can observe that terminally differentiated B cells are under BLyS influence but do not express the CD20 molecule, thus belimumab is expected to act faster, providing a milder immunesuppression, which is favorable by safety issues.

Up to the present, two phase III RCTs have been performed with belimumab $[8,9]$. The arrangement and protocols were similar; therefore combined results have also been analyzed. Antinuclear antibodies (ANA) or antids(double stranded)DNA positive patients with moderately active lupus were targeted. Pooled data from the two trials indicated that a significantly higher number of patients achieved good response with both 1 and $10 \mathrm{mg} / \mathrm{kg}$ belimumab at week 52 as compared to the placebo group [8]. Furthermore, the duration of response was longer in the treated groups and the higher the belimumab dosage, the more likely corticosteroids could be reduced. In this treatment arm, patients flared less frequently as indicated by the SLE flare index (SFI) and also by flare rates at week 52. Actually, however, the second phase III study, BLISS 76 , could not prove a positive sustained effect after 76 weeks [9] and it has to be noted that these studies did not recruit patients with severe LN or central nervous system (CNS) involvement. Hence, many aspects in the use of belimumab remain to be clarified in real-life SLE [29], including the clinical relevance of the differences in comparison to the placebo arm; the impact of the 
relatively short term effect; the effect of belimumab in treatment of refractory severe disease, including renal and CNS lupus; and finally, the balance between clinical benefit and cost.

Besides belimumab, sub-cutaneous drugs blocking soluble or receptor-bound BLyS are currently being tested in phase III RCTs [1], which in case of efficacy would provide a greater advantage in terms of administration route (subcutaneous vs. intravenous) and the patients' comfort and compliance.

A second drug aimed at suppressing the stimulation of $B$ cells was atacicept, a chimeric molecule against APRIL. The phase II study of atacicept in patients with LN was, however, terminated after recruiting six patients because of an unexpected decrease in immunoglobulin levels and an increased number of infections [6].

\section{T-cell targeted therapies}

$\mathrm{B}$ and $\mathrm{T}$ lymphocytes and antigen presenting cells (APCs), may communicate directly with each other. CTLA4-Ig (abatacept) is a fusion protein that blocks the interaction within the CD86/80-CD28 stimulatory molecular pair, inhibiting the interaction between APCs and T cells, cytokine production and subsequent stimulation of $\mathrm{B}$ cells. Abatacept was tested in two large double-blind RCTs in non-renal lupus and in patients with LN which did not meet their primary endpoints in prevention of disease flares [10], despite studies on animal models providing beneficial effects [30]. Nevertheless, post-hoc analysis revealed less frequent flares in treated group as compared to the placebo [31], suggesting definitions of disease flare might have blurred clinically meaningful results albeit not statistically significant. Particularly, abatacept seems to have prevented BILAG A polyarthritis flares in patients displaying non-lifethreatening SLE manifestations [10].

\section{Other treatment options: TNF-blocking therapies}

The role of tumor necrosis factor alpha (TNF $\alpha$ ) and its inhibition in lupus is debated. High levels of TNF $\alpha$ were demonstrated in human tissue samples [32] and the serum of SLE patients, where they correlated with disease activity; mouse models were likewise shown to reflect the same picture [33]. To date, open-label experience on a small patient series displaying refractory lupus manifestations brought to light some positive results. Refractory LN, skin lesions, hemophagocytic syndrome and arthritis showed beneficial effects following TNF $\alpha$-depleting therapies $[34,35]$. Moreover, some pilot studies [17,34] demonstrated an improvement in Systemic Lupus Erythematosus Disease Activity Index (SLEDAI) and Systemic Lupus International Collaborating Clinics (SLICC) index upon TNF $\alpha$ depletion, suggesting TNF $\alpha$-blockers could be taken into account as short-term induction therapy when dealing with refractory SLE. It is worth noting that no large controlled studies are yet available on anti-TNF $\alpha$ depletion in human SLE, therefore, no certain inference can be made.

Some other cytokines (IL-6, interferon alpha (IFN $\alpha$ )) are being explored as putative future therapeutic targets. Tocilizumab (anti-IL6R monoclonal antibody) use in a phase I trial seemed to decrease disease activity [18]. Likewise, interference with IFN $\alpha$ signaling might dampen DC and autoreactive B cells activation [19]. However, the data set is still very limited and no conclusions can be drawn on the disease course.

\section{Discussion and conclusions}

To date, the only RCTs that succeeded and achieved their primary endpoints were BLISS-52 and BLISS-76, leading to approval of belimumab for mild-to-moderate SLE. Belimumab is the first drug dedicated to SLE 50 years after corticosteroids and antimalarials, meaning no other firm evidence could be drawn so far for any other treatment ranging from traditional immunosuppressants to new biologic drugs. This is probably due to the great heterogeneity of the disease [35], which makes it unlikely that one treatment may be suitable for all patients. These aspects should be considered when turning to RCTs, since generalization of results - either promising or disappointing - is a thorny matter in SLE [36]. Ironically, most of the target populations enrolled in RCTs are on the one hand too small to represent the entire disease variability and especially most severe lupus manifestations, and on the other hand they are not small enough to focus on benefits which may be gained by discrete patient subgroups, though not by the general population. Consistently, patients belonging to African American or Hispanic ethnicity showed positive results in RCTs which had globally failed [23], suggesting study designs are sometimes objectionable in regard to outcome measures, background medications (for example, high dose corticosteroids overwhelming any positive effect of the new drug) or shortness of follow-up period [1,23]. Moreover, since severely affected patients (for example, CNS involvement, refractory LN) are frequently excluded from RCTs, information on an emerging drug in the case of life-threatening manifestations is lacking [1]. Though going back to non-controlled trials or basing conclusions on post-hoc analysis would not be scientifically acceptable, endpoint definitions should reasonably correlate with clinical practice in order to provide useful indications and limit the need for off-label use of new drugs. Indeed, excessive outcome stringency (for example, no BILAG B allowed, complete renal response required) is hardly ever met in lupus, whereas partial remission or improvement in organ-specific (non-generalized) alterations is far more frequent and acceptable, yet not optimal [37]. These considerations aside, it also has to be kept in mind that compelling evidence may diverge from intuitive premises, preclinical 
studies and open-label trials because of the true limited efficacy of a developing drug or methodological mistakes which have to be carefully considered.

Deeper knowledge of the underlying mechanisms of lupus [35] will hopefully lead to generation of more effective targeted therapies which would both affect disease course and minimize treatment-related adverse events; nevertheless, a detailed picture of patient status [38] will always be required for the most suitable therapeutic approach to be tailored.

\section{Competing interests}

The authors declare that they have no competing interest.

\section{Authors' contributions}

$E K, Y N, A D$ and $M G$ collected data on studies and wrote different sections of the manuscript. MG merged all text and AD revised the paper. All authors read and approved the final manuscript.

\section{Author details}

${ }^{1}$ Division of Rheumatology, University of Padova, Via Giustiniani, 2, 35128 Padova, Italy. ${ }^{2}$ Department of Clinical Immunology, Adult- and Paediatric Rheumatology, National Institute of Rheumatology and Physiotherapy, Budapest, Hungary. ${ }^{3}$ Rheumatology Division, 3rd Department of Internal Medicine, Semmelweis University, Budapest, Hungary. ${ }^{4}$ Senior Deputy Director General for Research and Academic Affairs, Hadassah Medical Organization, Hadassah Hebrew University Medical Center, Jerusalem 12000, Israel.

Received: 27 January 2014 Accepted: 27 January 2014

Published: 17 Feb 2014

\section{References}

1. Stohl W: Future prospects in biologic therapy for systemic lupus erythematosus. Nat Rev Rheumatol 2013, 9:705-720.

2. Merrill JT, Neuwelt CM, Wallace DJ, Shanahan JC, Latinis KM, Oates JC, Utset TO, Gordon C, Isenberg DA, Hsieh HJ, Zhang D, Brunetta PG: Efficacy and safety of rituximab in moderately-to-severe active systemic lupus erythematosus. Arthritis Rheum 2010, 62:222-233.

3. Furie R: Efficacy and safety of rituximab in subjects with active proliferative lupus nephritis (LN): results from the randomized, double-blind, phase III LUNAR study. Arthritis Rheum 2009, 60:16-21.

4. Postal M, Costallat LT, Appenzeller S: Biological therapy in systemic lupus erythematosus. Int J Rheumatol 2012, 2012:578641.

5. Wallace DJ, Kalunian K, Petri MA, Strand V, Houssiau FA, Pike M, Kilgallen B, Bongardt S, Barry A, Kelley L, Gordon C: Efficacy and safety of epratuzumab in patients with moderate/severe active systemic lupus erythematosus: results from EMBLEM, a phase $\mathrm{llb}$, randomised, double-blind, placebo-controlled, multicentre study. Ann Rheum Dis 2014 73:183-190.

6. Ginzler EM, Wax S, Rajeswaran A, Copt S, Hillson J, Ramos E, Singer NG: Atacicept in combination with MMF and corticosteroids in lupus nephritis: results of a prematurely terminated trial. Arthritis Res Ther 2012, 14:R33.

7. Dörner T, Kaufmann J, Wegener WA, Teoh N, Goldenberg DM, Burmester GR: Initial clinical trial of epratuzumab (humanized anti-CD2 antibody) for immune therapy of systemic lupus erythematosus. Arthritis Res Ther 2006, 8:R74.

8. Navarra SV, Guzmán RM, Gallacher AE, Hall S, Levy RA, Jimenez RE, Li EK, Thomas M, Kim HY, León MG, Tanasescu C, Nasonov E, Lan JL, Pineda L, Zhong ZJ, Freimuth W, Petri MA, BLISS-52 Study Group: Efficacy and safety of belimumab in patients with active systemic lupus erythematosus: a randomised, placebo-controlled, phase 3 trial. Lancet 2011, 377:721-731.

9. Furie R, Petri M, Zamani O, Cervera R, Wallace DJ, Tegzová D, Sanchez-Guerrero J, Schwarting A, Merrill JT, Chatham WW, Stohl W, Ginzler EM, Hough DR, Zhong ZJ, Freimuth W, van Vollenhoven RF, BLISS-76 Study Group: A phase III, randomized, placebo-controlled study of belimumab, a monoclonal antibody that inhibits B lymphocyte stimulator, in patients with systemic lupus erythematosus. Arthritis Rheum 2011, 63:3918-3930.

10. Merrill JT, Burgos-Vargas R, Westhovens R, Chalmers A, D'Cruz D, Wallace DJ, Bae SC, Sigal L, Becker JC, Kelly S, Raghupathi K, Li T, Peng Y, Kinaszczuk M, Nash P: The efficacy and safety of abatacept in patients with non-life-threatening manifestations of systemic lupus erythematosus: results of a twelve-month, multicenter, exploratory, phase llb, randomized, double-blind placebo-controlled trial. Arthritis Rheum 2010, 62:3077-3087.

11. Kalunian KC, Davis JC Jr, Merrill JT, Totoritis MC, Wofsy D, IDEC-131 Lupus Study Group: Treatment of systemic lupus erythematosus by inhibition of T cell costimulation with anti-CD154: a randomized, double-blind, placebo-controlled trial. Arthritis Rheum 2002, 46:3251-3258.

12. Sidiropoulos Pl, Boumpas DT: Lessons learned from anti-CD40L treatment in systemic lupus erythematosus patients. Lupus 2004, 13:391-397.

13. Sanz I, Lee FE: B cells as therapeutic targets in SLE. Nat Rev Rheumatol 2010, 6:326-337.

14. Lateef A, Petri M: Biologics in the treatment of systemic lupus erythematosus. Curr Opin Rheumatol 2010, 22:504-509.

15. Reddy V, Jayne D, Close D, Isenberg D: B-cell depletion in SLE: clinical and trial experience with rituximab and ocrelizumab and implications for study design. Arthritis Res Ther 2013, 15:\$2.

16. Kontoyiannis D, Kollias G: Accelerated autoimmunity and lupus nephritis in NZB mice with an engineered heterozygous deficiency in tumor necrosis factor. Eur Immunol 2000, 30:2038-2047.

17. Uppal SS, Hayat SJ, Raghupathy R: Efficacy and safety of infliximab in active SLE: a pilot study. Lupus 2009, 18:690-697.

18. Illei GG, Shirota Y, Yarboro CH, Daruwalla J, Tackey E, Takada K, Fleisher T, Balow JE, Lipsky PE: Tocilizumab in systemic lupus erythematosus: data on safety, preliminary efficacy, and impact on circulating plasma cells from an open-label phase I dosage-escalation study. Arthritis Rheum 2010, 62:542-552.

19. Merrill JT, Wallace DJ, Petri M, Kirou KA, Yao Y, White Wl, Robbie G, Levin R, Berney SM, Chindalore V, Olsen N, Richman L, Le C, Jallal B, White B, Lupus Interferon Skin Activity (LISA) Study Investigators: Safety profile and clinical activity of sifalimumab, a fully human anti-interferon a monoclonal antibody in systemic lupus erythematosus: a phase I, multicentre, double-blind randomized study. Ann Rheum Dis 2011, 70:1905-1913.

20. Terrier B, Amoura Z, Ravaud P, Hachulla E, Jouenne R, Combe B, Bonnet C, Cacoub P, Cantagrel A, de Bandt M, Fain O, Fautrel B, Gaudin P, Godeau B, Harlé JR, Hot A, Kahn JE, Lambotte O, Larroche C, Léone J, Meyer O, Pallot-Prades B, Pertuiset E, Quartier P, Schaerverbeke T, Sibilia J, Somogyi A, Soubrier M, Vignon E, Bader-Meunier B, et al: Safety and efficacy of rituximab in systemic lupus erythematosus: results from 136 patients from the French Autoimmunity and Rituximab registry. Arthritis Rheum 2010, 62:2458-2466.

21. Diaz-Lagares C, Croca S, Sangle S, Vital EM, Catapano F, Martínez-Berriotxoa A, García-Hernández F, Callejas-Rubio JL, Rascón J, D'Cruz D, Jayne D, Ruiz-Irastorza G, Emery P, Isenberg D, Ramos-Casals M, Khamashta MA, UK-BIOGEAS Registry: Efficacy of rituximab in 164 patients with biopsy-proven lupus nephritis: pooled data from European cohorts. Autoimmun Rev 2012, 11:357-364.

22. Ramos-Casals M, García-Hernández FJ, de Ramón E, Callejas JL, Martínez-Berriotxoa A, Pallarés L, Caminal-Montero L, Selva-O'Callaghan A, Oristrell J, Hidalgo C, Pérez-Alvarez R, Micó ML, Medrano F, Gómez de la Torre R, Díaz-Lagares C, Camps M, Ortego N, Sánchez-Román J, BIOGEAS Study Group: Off-label use of rituximab in 196 patients with severe, refractory systemic autoimmune diseases. Clin Exp Rheumatol 2010, 28:468-476.

23. Weidenbusch M, Römmele C, Schröttle A, Anders HJ: Beyond the LUNAR trial. Efficacy of rituximab in refractory lupus nephritis. Nephrol Dial Transplant 2013, 28:106-111.

24. Condon MB, Ashby D, Pepper RJ, Cook HT, Levy JB, Griffith M, Cairns TD, Lightstone L: Prospective observational single-centre cohort study to evaluate the effectiveness of treating lupus nephritis with rituximab and mycophenolate mofetil but no oral steroids. Ann Rheum Dis 2013, 72:1280-1286

25. Bertsias GK, Tektonidou M, Amoura Z, Aringer M, Bajema I, Berden JH, Boletis J, Cervera R, Dörner T, Doria A, Ferrario F, Floege J, Houssiau FA, loannidis JP, Isenberg DA, Kallenberg CG, Lightstone L, Marks SD, Martini A, Moroni G, Neumann I, Praga M, Schneider M, Starra A, Tesar V, Vasconcelos C, van Vollenhoven RF, Zakharova H, Haubitz M, Gordon C, et al: Joint European League Against Rheumatism and European Renal Association-European 
Dialysis and Transplant Association (EULAR/ERA-EDTA) recommendations for the management of adult and paediatric lupus nephritis. Ann Rheum Dis 2012, 71:1771-1782.

26. Dörner T, Goldenberg DM: Targeting CD22 as a strategy for treating systemic autoimmune diseases. Ther Clin Risk Manag 2007, 3:953-959.

27. Wallace DJ, Gordon C, Strand V, Hobbs K, Petri M, Kalunian K, Houssiau F, Tak PP, Isenberg DA, Kelley L, Kilgallen B, Barry AN, Wegener WA, Goldenberg DM: Efficacy and safety of epratuzumab in patients with moderate/severe flaring systemic lupus erythematosus: results from two randomized, double-blind, placebo-controlled, multicentre studies (ALLEVIATE) and follow-up. Rheumatology 2013, 52:1313-1322.

28. Cancro MP, D'Cruz DP, Khamashta MA: The role of B lymphocyte stimulator (BLyS) in systemic lupus erythematosus. J Clin Invest 2009, 119:1066-1073.

29. Ramos-Casals M, Sanz I, Bosch X, Stone JH, Khamashta MA: B-cell-depleting therapy in systemic lupus erythematosus. Am J Med 2012, 125:327-336.

30. Daikh DI, Wofsy D: Cutting edge: reversal of murine lupus nephritis with CTLA4Ig and cyclophosphamide. J Immunol 2001, 66:2913-2916.

31. Mok CC: Abatacept for systemic lupus erythematosus: the outlook. Expert Opin Biol Ther 2012, 12:1559-1561.

32. Zampieri S, Alaibac M, laccarino L, Rondinone R, Ghirardello A, Sarzi-Puttini P, Peserico A, Doria A: Tumour necrosis factor alpha is expressed in refractory skin lesions from patients with subacute cutaneous lupus erythematosus. Ann Rheum Dis 2006, 65:545-548.

33. Aringer M, Smolen JS: Therapeutic blockade of TNF in patients with SLE - promising or crazy? Autoimmun Rev 2012, 11:321-325.

34. Matsumura R, Umemiya K, Sugiyama T, Sueishi M, Umibe T, Ichikawa K, Yoshimura M, Study Group on Nephrology at the National Hospital Organization of Japan: Anti-tumor necrosis factor therapy in patients with difficult-to-treat nephritis: a prospective series of nine patients. Clin Exp Rheumatol 2009, 27:416-421.

35. Gatto M, Zen M, Ghirardello A, Bettio S, Bassi N, laccarino L, Punzi L, Doria A: Emerging and critical issues in the pathogenesis of lupus. Autoimmun Rev 2013, 12:523-536.

36. van Vollenhoven RF: Challenges and opportunities in SLE clinical trials. Curr Opin Rheumatol 2013, 25:606-615.

37. Doria A, Gatto M, Zen M, laccarino L, Punzi L: Optimizing outcome in SLE: treating-to-target and definition of treatment goals. Autoimmun Rev 2014, Jan 27 [Epub ahead of print].

38. Zen M, Bassi N, Nalotto L, Canova M, Bettio S, Gatto M, Ghirardello A, laccarino $L$, Punzi $L$, Doria A: Disease activity patterns in a monocentric cohort of SLE patients: a seven-year follow-up study. Clin Exp Rheumatol 2012, 30:856-863.

10.1186/1741-7015-12-30

Cite this article as: Gatto et al.: In-/off-label use of biologic therapy in systemic lupus erythematosus. BMC Medicine 2014, 12:30

\section{Submit your next manuscript to BioMed Central and take full advantage of:}

- Convenient online submission

- Thorough peer review

- No space constraints or color figure charges

- Immediate publication on acceptance

- Inclusion in PubMed, CAS, Scopus and Google Scholar

- Research which is freely available for redistribution 